\title{
GEBRAKAN DAN PENGANEKARAGAMAN: BUDAYA PERSAINGAN DALAM PERTUMBUHAN SENI PERTUNJUKAN RAKYAT DI BOYOLALI JAWA TENGAH
}

\section{GEBRAKAN AND DIVERSIFICATION: CULTURE OF COMPETITION IN THE GROWTH OF FOLK PERFORMING ARTS IN BOYOLALI, CENTRAL JAVA}

\author{
${ }^{* 1}$ Kiswanto, ${ }^{2}$ Tri Joko, ${ }^{3}$ Aris Dwiyanto \\ ${ }^{1}$ PUI-PT Choreographyc \& Artistic Research ISI Surakarta, dan Dosen Pengajar di Program \\ Studi S-1 Etnomusikologi, Fakultas Seni Pertunjukan, Institut Seni Indonesia Surakarta \\ ${ }^{2}$ Mahasiswa Program Studi S-1 Seni Karawitan, Fakultas Seni Pertunjukan, Institut Seni \\ Indonesia Surakarta \\ ${ }^{3}$ Mahasiswa Program Studi S-1 Etnomusikologi, Fakultas Seni Pertunjukan, Institut Seni \\ Indonesia Surakarta
}

Submitted: 08-05-2021; Revised: 06-08-2021; Accepted:09-08-2021

\begin{abstract}
This study aims to reveal and explain the cultural practice of competition in the growth of folk performing arts in Boyolali through the monopolistic competition theory approach of Edward Hastings Chamberlin, which has been adapted and developed critically with ethnographic research methods. This research produces findings in the form of a cultural pattern of competition that occurs indirectly among folk performing arts communities in Boyolali. Its characteristics can be recognized by the pattern of development and diversification of works of art between communities which is carried out by adding and producing forms of art that are distinguished from one another. This pattern is built through the process and the result of creativity from the practice of developing, creating, and/or adopting art forms based on the intention to create and present a gebrakan. On the other hand, this process is also part of the diversification process carried out as a strategy to strengthen the community's positioning in facing market competition. The patterns and strategies developed in it have had a positive impact on the growth of folk performing arts which are increasingly diverse, so that there are many choices of competing art forms that can be chosen to be seen or ordered to be performed.
\end{abstract}

Keywords: Gebrakan; Folk Performing Arts; Competition; Artwork Differentiation; Diversification.

\section{ABSTRAK}

Penelitian ini bertujuan untuk mengungkap dan menjelaskan praktik budaya persaingan dalam pertumbuhan seni pertunjukan rakyat di Boyolali melalui pendekatan teori monopolistic competition dari Edward Hastings Chamberlin yang diadaptasikan dan dikembangkan secara kritis dengan metode penelitian etnografi. Penelitian ini menghasilkan temuan berupa pola budaya persaingan yang terjadi

${ }^{*}$ Corresponding author: kiswanto881@gmail.com.

Copyright@ 2021 THE AUTHOR (S). This article is distributed under a Creative Commons Attribution-Share Alike

4.0 International license. Jurnal Kawistara is published by the Graduate School of Universitas Gadjah Mada. 
secara tidak langsung pada antar komunitas seni pertunjukan rakyat di Boyolali. Ciri-cirinya dapat dikenali dengan adanya pola pengembangan dan penganekaragaman karya seni pada antar komunitas yang dilakukan dengan cara menambahkan dan menghasilkan bentuk-bentuk karya seni yang saling dibedakan satu sama lain. Pola tersebut terbangun melalui proses dan hasil kreativitas dari praktik pengembangan, penciptaan, dan/atau adopsi bentuk karya seni yang didasari atas maksud untuk membuat dan menghadirkan suatu gebrakan. Di sisi lain, proses tersebut juga menjadi bagian dari proses penganekaragaman yang dilakukan sebagai strategi untuk memperkuat positioning komunitas dalam menghadapi persaingan pasar. Pola dan strategi yang terbangun di dalamnya telah memberikan dampak positif terhadap pertumbuhan seni pertunjukan rakyat yang semakin bertambah banyak ragamnya, sehingga tersedia banyak pilihan bentuk karya seni yang saling bersaing agar dapat dipilih untuk disaksikan ataupun dipesan untuk dipergelarkan.

Kata Kunci: Gebrakan; Seni Pertunjukan Rakyat; Persaingan; Pembedaan Karya Seni; Penganekaragaman.

\section{PENGANTAR}

Seni pertunjukan tradisional kerakyatan yang tumbuh di wilayah-wilayah pedesaan dengan pelakunya adalah kalangan rakyat biasa (pekerjaan utamanya bukan sebagai seniman), umumnya sering dipandang dengan ciri-ciri yang sederhana, baik bentuknya, susunannya, bahannya, maupun pelaksanannya (lihat Pigeaud, 1991: 1; Soemaryatmi \& Suharji, 2015: 38). Konsepsi semacam itu menjadi perhatian dan kajian yang menarik di bidang seni pertunjukkan rakyat ketika dikaitkan dengan kondisi pertumbuhan seni pertunjukan rakyat di Jawa yang terus berlangsung sampai saat ini. Sejak era kemerdekaan Indonesia, seni pertunjukan rakyat di Indonesia secara bertahap telah mengalami perkembangan (Soedarsono, 2010: 83-84), bahkan tampak semakin kompleks dan beragam dalam dua dekade terakhir, terutama ketika mengamati perkembangan seni pertunjukan rakyat yang terdapat di Kabupaten Magelang, Semarang, Temanggung, dan Boyolali Provinsi Jawa Tengah (lihat juga Fitriasari dkk., 2012: 26).
Seni pertunjukan tradisional kerakyatan di wilayah Kabupaten Boyolali menjadi perhatian utama dalam penelitian ini, khususnya terkait pertumbuhannya yang semakin pesat karena tercipta budaya persaingan yang terjadi di dalamnya. Budaya dalam hal ini dapat diartikan sebagai suatu kebiasaan (custom) dan cara hidup (way of life) berkesenian yang terus dipelihara secara dialogis dan dialektis di antara komunitas-komunitas seni pertunjukan rakyat di Boyolali, termasuk dimensi pengetahuan, kreativitas, dan nilai-nilai yang terkandung di dalamnya. Pengertian tersebut diadopsi dan diadaptasikan dari penjelasan Tylor (1871: 1) mengenai budaya, yang memaknai budaya secara lebih luas. Menurut Tylor budaya diartikan sebagai berikut: "...that complex whole which includes knowledge, belief, art, law, morals, custom, and any other capabilities and habits acquired by man as a member of society". Budaya yang dipahami sebagai cara hidup sebagaimana yang dijelaskan oleh Williams dan Bennett. Menurut pandangan Williams (1965: 63) dan Bennett (2015:546), budaya diartikan sebagai cara hidup (way of life). Pengertian mengenai budaya yang diadosi dan diadaptasi dalam praktik persaingan tersebut tidak jauh berbeda dengan penjelasan Rice (2014: 65) mengenai budaya pada frasa 'music as culture', yaitu "... all forms of human knowledge, creativity, and values, and to their expression in music...". Jadi, budaya persaingan (competition as culture) adalah segala bentuk pengetahuan manusia, kreativitas, dan nilai-nilai, serta ekspresinya dalam praktik persaingan yang menjadi kebiasaan serta cara hidup komunitas dalam berkegiatan kesenian.

Pertumbuhan berkesenian dengan persaingan merupakan dua hal yang saling berkaitan dalam kehidupan seni pertunjukan rakyat di Boyolali. Pertumbuhan tersebut mulai tampak semenjak tahun 2000-an pada beberapa komunitas yang ditandai dengan munculnya karya-karya baru sebagai hasil dari kreativitas pengembangan serta pemberagaman dari bentuk-bentuk seni pertunjukan tradisional yang sebelumnya telah ada (Kiswanto, 2018: 170-171). Komunitas-komunitas lain di sekitarnya kemudian secara berangsur-angsur dan bertahap juga melakukan kreativitas yang 
serupa untuk memperjuangkan eksistensinya agar terhindar dari kejenuhan terhadap karyakarya lama, serta mampu bersaing dengan karya-karya komunitas lain dalam rangka memenuhi kebutuhan pasar. Sejak saat itu juga banyak bermunculan komunitas-komunitas seni pertunjukan rakyat yang didirikan di berbagai Desa dari yang tidak mempunyai komunitas seni pertunjukan tradisional kerakyatan.

Berdasarkan Data Kelompok Kesenian Kabupaten Boyolali Tahun 2017 dari Dinas Pendidikan dan Kebudayaan Kabupaten Boyolali, telah tercatat (namun belum semuanya) bahwa terdapat kurang lebih 97 komunitas seni pertunjukan tradisional kerakyatan yang hidup dan berkembang di Kabupaten Boyolali (Dinas Pendidikan dan Kebudayaan Kabupaten Boyolali, 2017). Pada umumnya seni pertunjukan tersebut merupakan bentuk-bentuk tari berkelompok dengan tema tertentu yang diiringi dengan sajian bentuk musik secara ensambel, serta dilengkapi dengan pendukung unsur-unsur visual seperti tata rias dan kostum tari, properti tari, dan setting tempat pertunjukan. Jenis-jenis seni pertunjukan yang jumlahnya cukup mendominasi dan dikembangkan pada banyak komunitas adalah seni pertunjukan Kuda Kepang, Topeng Ireng, dan terakhir sedang berkembang Buto Gedruk. Di luar itu masih banyak jenis seni pertunjukan rakyat yang berkembang di tengah-tengah masyarakat meskipun jumlahnya hanya sedikit, seperti seni pertunjukan Soreng, Jalantur, Jangkrik Ngentir, Badui, Kubro Siswo, Jathilan Blendrongan, Jathilan Campur Bawur, Rudat, Angguk, Sakera, Prajuritan, Lembu Kanaka, dan Goro-goro.

Setiap komunitas pada umumnya tidak hanya mengembangkan satu bentuk seni pertunjukan saja, melainkan mengembangkan lebih dari satu jenis seni pertunjukan tradisional melalui praktik pemberagaman agar dapat dipilih salah satu, sebagian, dan bahkan semuanya oleh calon penanggap. Semuanya hampir sama-sama memiliki keinginan dan tujuan untuk ditanggap oleh calon pemesan atau pembelinya (penanggap) agar dapat dipergelarkan dan dikenal masyarakat lebih luas. Persaingan antar komunitas yang jumlahnya juga semakin bertambah banyak dengan berbagai ragam karya seni yang dimiliki masing-masing telah tumbuh menjadi suatu kebiasaan yang terus dipelihara secara dialogis dan dialektis hingga saat ini. Persaingan dalam hal ini memiliki kemiripan dengan konsep persaingan yang dijelaskan oleh Mesoudi (2011: 29-30) dalam paradigma evolusionisme, yaitu terjadi ketika individu-individu dan/ atau kelompok-kelompok individu yang terus mengalami peningkatan populasi secara eksponensial memiliki kebutuhan dan tujuan yang sama untuk mendapatkan ketersediaan sumber daya yang terbatas. Persaingan untuk mendapatkan ketersediaan sumber daya yang terbatas menjadi suatu hal yang tidak terelakkan agar individu-individu atau kelompokkelompok individu tetap dapat bertahan hidup, bereproduksi, serta melanjutkan proses regenerasinya. Begitu pun dalam kehidupan komunitas seni pertunjukan yang dalam kontinuitas kekaryaan (reproduksi) dan proses regenerasinya (pewarisan) memerlukan tiga sumber daya utama yang saling mendukung satu sama lain, yaitu masyarakat pelaku seni, karya seni, serta masyarakat yang menjadi penikmat atau audience dari karya seni tersebut (lihat Murgiyanto, 2017: 7).

Persaingan yang terjalin dan terjadi di antara komunitas-komunitas seni pertunjukan rakyat di Boyolali dapat terjadi secara langsung maupun tidak langsung. Persaingan yang terjadi secara langsung dapat diamati dengan ciri-ciri yang terlihat melalui perjumpaan langsung dalam ruang dan waktu yang ditentukan, misalnya seperti dalam event perlombaan dan festival yang mempertemukan beberapa komunitas untuk menampilkan hasil kekaryaan masing-masing. Persaingan yang terjadi secara tidak langsung adalah bersifat implisit karena prosesnya tidak terjadi melalui perjumpaan langsung dan berlangsung dalam ruang dan waktu yang tidak ditentukan, namun memiliki porsi yang cukup besar sebagai bagian dari proses kultural yang terus dipelihara tanpa harus menunggu adanya momen perlombaan maupun festival. Persaingan yang terjadi secara tidak langsung menjadi perhatian utama dalam penelitian ini, sebab prosesnya 
terjadi dalam praktik pengembangan karya seni antar komunitas yang cenderung saling dibedakan satu sama lain. Pembedaan tersebut adalah untuk menunjukkan keunikan dan daya tarik masing-masing komunitas dalam rangka memperjuangkan eksistensinya agar dapat bertahan hidup dan berkembang di tengah-tengah banyaknya pilihan ragam seni yang tersedia untuk melayani permintaan penanggap (pasar). Persaingan yang implisit melalui pembedaan karya tersebut mirip dengan jenis persaingan monopolistik (monopolistic competition) dalam dunia industri barang maupun jasa yang diistilahkan oleh Hunt (2011: 75) “...is characterized by product differentiation implies that there is a form of competition (monopolistic competition) that is a blend of competition and monopoly" (lihat juga Chamberlin, 1969: 191).

Persaingan monopolistik merupakan bentuk penggabungan antara bentuk persaingan murni (pure competition) dan monopoli. Edward Hastings Chamberlin (1969: 7) sebagai seorang ahli ilmu ekonomi dari Amerika yang menjadi pencetus dan peletak dasar dari teori tersebut menjelaskan bahwa dalam monopoli, pelaku usaha ataupun penjual memegang kendali penuh atas persediaan barang (atau jasa) beserta harganya, sedangkan persaingan murni adalah sebaliknya karena terdiri dari banyak pembeli dan penjual atas produk dan harga yang benar-benar homogen dan terstandarisasi. Persaingan monopolistik jelas berbeda dengan monopoli maupun persaingan murni, namun menjadi bentuk persaingan tersendiri yang menggabungkan unsur di antara keduanya. Di dalamnya terdapat banyak produsen ataupun penjual seperti dalam persaingan murni, namun produknya adalah bersifat hetererogen karena setiap produsen atau penjual melakukan diferensiasi produk dari kelas umum pada kategori yang sama, sedangkan pembeli memiliki keleluasaan untuk menentukan pilihannya terhadap keberagaman produk yang tersedia dan ditawarkan (lihat Chamberlin, 1969: 56; Hunt, 2011: 75-76; dan Marcuello dan Salas, 2001: 187).

Chamberlin menjelaskan bahwa pembedaan (diferensiasi) produk berpotensi mencipta- kan pasar sendiri bersama konsumennya karena tidak adanya ketersediaan (supply) produk yang sama untuk melayani permintaan (demand) pasar (Chamberlin, 1969: 56 \& 65). Diferensiasi dapat dikategorikan sebagai bentuk monopoli penyediaan produk karena ketidakserupaannya dengan produk-produk lain dari kompetitor, namun hal ini bukan sepenuhnya monopoli karena produsen atau penjual tidak memegang kendali penuh (satusatunya) atas persediaan produk dan harga di dalam pasar. Kendali produsen atas persediaan produk dan harganya yang berarti monopoli hanya diterapkan pada beberapa level atau bagian yang dibedakan dari kategori umum, sehingga pembedaan bersifat sebagai preferensi yang ditawarkan untuk melayani permintaan pasar (Chamberlin, 1969: 65-67 \& 71-73).

Strategi diferensiasi merupakan fenomena yang sangat lazim terjadi di dalam dunia kekaryaan seni pertunjukan, baik kekaryaan dalam menghasilkan karya baru melalui praktik pengembangan dari jenis seni pertunjukan yang telah ada, maupun kekaryaan dalam kegiatan penciptaan seni dengan jenis yang baru. Sebelumnya Kiswanto (2018: 165) telah menjelaskan mengenai strategi komunitas Turonggo Seto Mardi Utomo di Boyolali yang cukup berhasil dalam upaya memenangkan persaingan pasar, yaitu dengan cara menambahkan dan menghasilkan bentuk karya seni yang berbeda dari yang telah dimiliki sebelumnya serta sekaligus berbeda dengan berbagai macam bentuk seni pertunjukan rakyat yang tumbuh di sekitarnya. Strategi tersebut telah dilakukan berulangkali hingga menghasilkan beragam karya seni yang berdeda satu sama lain, antara lain adalah tari Reog, tari Turonggo Seto, tari Turonggo Kencono, tari Keprajuritan Nusantara, tari Prajurit Tamtama, dan karya-karya yang lainnya.

Strategi memenangkan persaingan pasar melalui pembedaan produk sebenarnya tidak hanya berlaku untuk komunitas Turonggo Seto Mardi Utomo saja, namun telah menjadi pola yang berlaku umum dan dipelihara oleh sebagian besar komunitas seni pertunjukan rakyat yang terdapat di Boyolali. Pola persaingan tersebut perlu diungkap dan 
dijelaskan lebih lanjut melalui penelitian ini, karena di dalamnya mengandung dimensi pengetahuan mengenai sebuah budaya persaingan seni yang tumbuh secara heterogen melalui kreativitas-kreativitas pembedaan produk di antara komunitas-komunitas yang terlibat di dalamnya. Persaingan semacam itu telah menjadi sebuah karakter kebudayaan berkesenian dalam masyarakat, yaitu tumbuh dan berkembang lewat model persaingan yang jika dikaitkan dengan penjelasan Chamberlin (1969: 56 \& 65) dapat dikategorikan sebagai bentuk persaingan monopolistik (monopolistic competition) dalam rangka memperebutkan dan meningkatkan pangsa pasar (lihat juga Hunt, 2011: 75-76; dan Marcuello dan Salas, 2001: 187).

Penelitian tentang persaingan seni pertunjukan tradisional di Indonesia sangat jarang sekali ditemukan. Penelitian-penelitian yang membahas dan/atau menyinggung tentang persoalan persaingan cenderung berfokus pada sebuah komunitas seni pertunjukan dalam upaya menghadapi persaingan, namun tanpa memperlihatkan ciri-ciri dan bentuk persaingan antar komunitas yang terjadi di dalamnya. Salah satunya adalah makalah yang ditulis oleh Nurngaeni dkk. (2019), yang memfokuskan pada aspek reproduksi seni pertunjukan Lengger Banyumasan pada kelompok seni Kencana Laras dalam perspektif Bourdieus yang menunjukkan adanya hubungan antara aktor dan struktur kepemilikan yang terdiri dari habitus, modal, dan arena. Di samping itu ada juga artikel yang ditulis oleh Radhia (2016) yang berfokus pada dinamika seni pertunjukan Jaran Kepang di kota malang yang telah mengalami banyak perubahan akibat inovasi-inovasi yang dilakukan dalam rangka menyesuaikan dan menyelaraskan dengan tuntutan dan kebutuhan pasar.

Topik penelitian sebelumnya yang memiliki keserupaan dengan kajian ini adalah artikel tentang kontestasi dan representasi identitas Using pada seni pertunjukan Gandrung Banyuwangi yang ditulis oleh Anoegrajekti (2011). Persoalan kontestasi yang dibahas di dalamnya bukan membahas pada aspek antar produk seni, melainkan proses pertarungan perebutan kekuasaan antara kekuatan birokrasi, agama, dan pasar kaitannya dalam mewujudkan hegemoni serta representasi identitas Using pada kesenian Gandrung. Ketiganya (birokrasi, agama, dan pasar) bersaing untuk menampilkan identitas Using yang berbeda melalui Gandrung, yaitu Gandrung yang berorientasi pasar, Gandrung tradisi, dan Gandrung islami.

Budaya persaingan yang terjadi di antara komunitas-komunitas seni pertunjukan rakyat di Boyolali menjadi topik utama yang akan diungkap dan dijelaskan dalam penelitian ini, khususnya untuk mengetahui pola dan strategi persaingan yang terjadi di dalamnya, serta dampaknya terhadap pertumbuhan bentuk seni pertunjukan yang semakin beranekaragam dan bervariasi. Penelitian ini hanya akan dibatasi pada beberapa objek yang bisa dikatakan cukup representatif untuk menjelaskan mengenai budaya persaingan tersebut, yaitu (1) komunitas Turonggo Seto Mardi Utomo yang beralamat di Dusun Salam, Desa Samiran, Kecamatan Selo, Kabupaten Boyolali, (2) komunitas Saleho Karya Budaya yang beralamat di Dusun Bendolegi, Kelurahan Cluntang, Kecamatan Musuk, Kabupaten Boyolali, dan (3) komunitas Kridho Mudo yang beralamat di Dusun Tarusari, Kelurahan Tarubatang, Kecamatan Selo, Kabupaten Boyolali.

Penelitian ini pada dasarnya berangkat dari data-data hasil pengamatan dan percakapan yang telah diperoleh penulis selama menjadi participant di tengah komunitas-komunitas seni pertunjukan rakyat di Boyolali. Kurang lebih semenjakterlibataktifsebagaianggotakomunitas Turonggo Seto Mardi Utomo (1998-sekarang) yang berasal dari Dusun (Salam, Samiran, Selo, Boyolali) yang sama dengan penulis, hingga pengalaman keterlibatan langsung dalam kegiatan kekaryaan dan pementasan karya seni bersama komunitas-komunitas seni pertunjukan rakyat di Boyolali yang lainnya. Beberapa di antaranya adalah komunitas Kridho Seto (2007-2014) Dusun Blambangan, Desa Gedhangan, Kecamatan Cepogo, Kabupaten Boyolali, serta komunitas Saleho Karya Budaya (2008-2010). Penelitian ini juga melibatkan dua penulis lain sebagai anggota, yaitu Tri Joko yang 
merupakan penduduk setempat dan anggota dari komunitas Saleho Karya Budaya, serta Aris Dwiyanto yang merupakan penduduk setempat dan anggota dari komunitas Kridho Mudo.

Penelitian ini secara metode lebih berdasar pada pendekatan etnografi dan modelnya termasuk dalam kategori penelitian etnografi dengan pertimbangan bahwa (1) data diperoleh langsung oleh peneliti melalui pengamatan dan wawancara, (2) setting (pengaturan) penelitian dilakukan dalam keadaan natural, (3) peneliti menjadi instrumen utama penelitian melalui membangun pengalaman dan pemahaman yang disertai dengan keterlibatan langsung di tengah-tengah masyarakat, dan (4) proses penelitian berjalan secara dialogis antara peneliti dengan informan untuk menggali informasi lebih jauh berdasarkan native point of view (sudut pandang pelaku atau masyarakat) (Simatupang, 2013: 93-94). Selain itu, (5) penelitian ini juga dilakukan melalui tahapan studi arsip, dokumentasi, serta studi kepustakaan. Data-data yang telah berhasil dikumpulkan kemudian diolah dengan menyeleksinya sesuai kebutuhan penelitian, selanjutnya dianalis dan dideskripsikan di atas kertas melalui metode interpretasi.

\section{PEMBAHASAN}

Budaya monopolistic competition kaitannya dalam penelitian ini dapat dimaknai secara khusus sebagai bentuk pola persaingan yang dibangun melalui proses saling berinovasi pada antar komunitas untuk mengembangkan dan menambahkan bentuk karya seni yang saling dibedakan satu sama lain. Persaingan dalam hal inovasi semacam itu telah menjadi kebiasaan yang terus dipelihara secara dialogis dan dialektis di antara komunitas-komunitas seni pertunjukan rakyat di Boyolali dalam upaya memperjuangkan eksistensinya agar tetap bertahan hidup dan berkembang sesuai dengan selera dan minat para pelaku dan masyarakat penikmatnya, serta agar semakin diminati oleh masyarakat dalam jangkauan yang lebih luas. Ciri-cirinya dapat dikenali dengan adanya pola pengembangan dan penganekaragaman karya seni pada antar komunitas yang dilakukan dengan cara menambahkan dan menghasilkan bentukbentuk karya seni yang saling dibedakan satu sama lain, baik dari karya-karya sendiri di dalam internal komunitas, maupun dari karyakarya komunitas-komunitas lain di sekitarnya.

Pemahaman atas teori monopolistic competition yang diadopsi dan diadaptasi dari disiplin ilmu ekonomi memiliki relevansi untuk menjelaskan fakta-fakta pertumbuhan seni pertunjukanyang terkaiterat dengan persaingan yang terjadi dan terjalin di dalamnya, namun pemakaian istilah 'persaingan' itu sendiri memiliki citra yang cenderung 'kurang pantas' apabila dinyatakan secara eksplisit di kalangan para pelaku seni dan komunitasnya. Hal itu setidaknya menunjukkan sikap kerendahan hati para pelaku seni bahwa persoalan 'ambisi' dan 'orientasi' untuk 'menguasai persaingan', 'menjadi pemenang', atau 'menjadi yang terbaik' merupakan hal yang kurang pantas untuk diperbincangkan di luar internal komunitas. Bagi mereka, kontinuitas kekaryaan, hasil kekaryaan, serta tingkat apresiasi penontonlah yang saling terkait akan menunjukkan dan membuktikan pencapaian atas semua itu. Kondisi tersebut barangkali juga berkaitan dengan sifat persaingannya yang implisit, tampak samar, dan bahkan terkesan ambigu antara "ya" dan "tidak". Pemahaman yang paling umum terhadap terjadinya pertumbuhan adalah karena adanya proses kreativitas untuk memenuhi perkembangan kebutuhan estetis antara pelaku seni dan masyarakat penikmatnya (pasar), tetapi fakta bahwa di dalamnya terdapat praktik diferensiasi karya seni antar komunitas telah menunjukkan adanya persaingan yang terjadi secara tidak langsung (lihat Marcuello dan Salas, 2001: 187 \& Mesoudi, 2011: 29-30).

Para pelaku lebih lazim menggunakan istilah setempat (lokal), yaitu gebrakan untuk menyebut serta menunjuk pada suatu proses dan hasil tindakan kreatif dalam upaya memperjuangkan eksistensi di tengah-tengah arus pertumbuhan dan persaingan bentuk seni yang sangat beragam di antara komunitas-komunitas seni pertunjukan rakyat yang ada di Boyolali. Gebrakan merupakan sebuah istilah yang digunakan untuk memetaforkan fenomena kekaryaan maupun 
pementasan karya seni yang tidak hanya sekedar menghasilkan kebaruan, melainkan juga menghasilkan daya tarik yang mampu memukau, mengejutkan, menghebohkan, dan memikat perhatian banyak orang untuk mengapresiasi dan mengagumi. Istilah tersebut berasal dari kata 'gebrag' yang artinya dalam kamus Bausastra Jawa (Poerwadarminta, 1939: 75) dapat dikategorikan sebagai bentuk onomatopoeia, yaitu kata atau istilah yang digunakan menerangkan bunyi-bunyi pukulan meja atau pintu melalui menirukan sumber bunyi aslinya. Gebrakan dalam kehidupan sehari-hari sering digunakan untuk menunjuk pada suatu sikap dan tindakan seseorang atau sekelompok orang yang membuat efek kejut atau kekagetan dalam rangka memberikan peringatan ataupun kejutan, sehingga apabila ditarik ke dalam penggunaannya untuk fenomena kekaryaan seni kurang lebih mengandaikan suatu kegiatan kekaryaan dan pementasan karya seni yang tidak hanya sekedar menghasilkan kebaruan, melainkan juga menghasilkan daya tarik yang mampu mengejutkan, menghebohkan, dan memikat perhatian banyak orang untuk mengapresiasi serta mengagumi.

Gebrakan-gebrakan yang umumnya terjadi di antara banyak komunitas adalah melakukan suatu proses kreativitas hingga menghasilkan bentuk karya seni yang baru dan berbeda dari karya-karya sendiri di dalam internal komunitas, maupun dari karya-karya komunitas-komunitas lain di sekitarnya. Istilah gebrakan dalam hal ini mengandung maksud sebagai tujuan dan harapan yang dalam penggunaannya dapat ditujukan untuk mengacu pada proses ataupun hasilnya, sehingga maksud dari gebrakan dapat berhenti pada proses ketika hasilnya tidak sesuai dengan yang diharapkan. Gebrakan ini di dalam prosesnya dapat dilakukan dengan tiga macam pilihan cara, yaitu melalui (1) praktik pengembangan karya seni, (2) praktik penciptaan karya seni, dan/atau (3) praktik adopsi karya seni.

\section{Gebrakan Melalui Pengembangan}

Gebrakan melalui pengembangan dapat diartikan sebagai suatu proses kreativitas untuk menghasilkan kebaruan bentuk karya seni dari yang telah ada sebelumnya, atau dalam istilah lokalnya adalah "nganyarke" (memperbarui). Biasanya dilakukan dengan cara meningkatkan unsur-unsur karya seni dari yang sederhana menjadi lebih kompleks, ataupun melalui praktik modifikasi dengan cara menambah dan/atau mengurangi unsurunsur karya seni. Kebaruan tersebut biasanya terletak dalam perihal gaya (style) ataupun unsur-unsur di dalam bentuk seni, namun masih tetap dalam genre atau jenis yang sama.

Gebrakan ini biasanya tidak hanya terjadi sekali atau dua kali saja, namun dapat terjadi berkali-kali yang tergantung pada kehendak dan realisasi komunitas dalam merespon dinamika perubahan kebutuhan estetis, permintaan pasar, dan situasi persaingan yang terjadi. Kondisi tersebut seperti dalam praktik pengembangan tari kuda kepang Turonggo Seto pada komunitas Turonggo Seto Mardi Utomo, tari Topeng Ireng pada komunitas Kridho Mudo, dan tari Buto Gedruk pada komunitas Saleho Karya Budaya. Gebrakan-gebrakan dari pengembangan bentuk seni di antara ketiganya diuraikan sesuai tahapan-tahapan dan konteksnya.

\section{Gebrakan Pengembangan Seni Pertunjukan Kuda Kepang Turonggo Seto Komunitas Turonggo Seto Mardi Utomo}

Seni pertunjukan tari kuda kepang Turonggo Seto pada komunitas Turonggo Seto Mardi Utomo merupakan bentuk seni perpaduan antara tarian dengan properti utama jaran kepang atau kuda kepang (boneka kuda yang terbuat dari anyaman bambu) yang menggambarkan tentang prajurit berkuda dan musik. Sebutan lain dari bentuk kesenian semacam itu adalah kesenian jaranan (tarian yang disajikan dengan menggunakan properti kuda-kudaan). Kesenian jaranan Turonggo Seto pada komunitas Turonggo Seto Mardi Utomo dikembangkan pertama kali pada tahun 1999 karena mendapatkan pengaruh (melalui proses adopsi dan adaptasi) dari perkembangan seni kuda kepang gaya Temanggung Jawa Tengah.

Pada tahun 2004 hingga 2005 kesenian jaranan Turonggo Seto dikembangkan lagi hingga mengalami perubahan bentuk garap yang cukup signifikan, namun masih tetap 


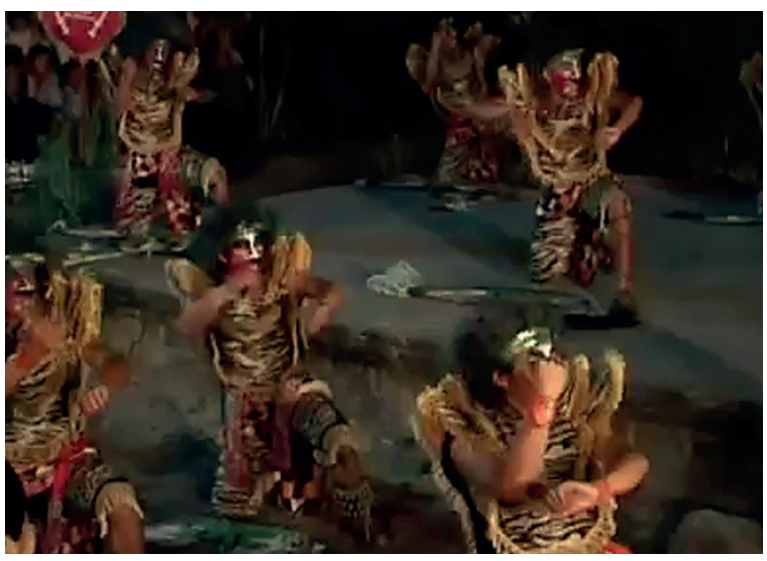

Gambar 1.

Penampilan tari Turonggo Seto binaan DISPARBUD Boyolali 2005

Sumber: Darminto Masyo Sudarmo, 2005.

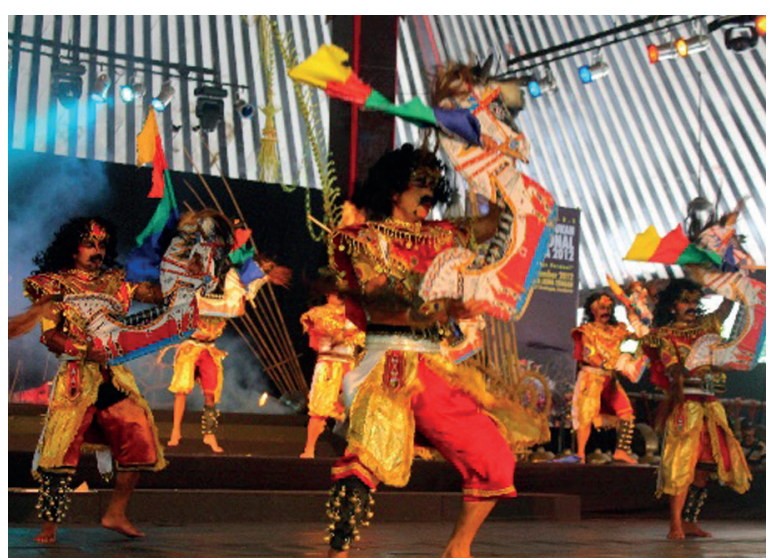

Gambar 2.

Penampilan tari Turonggo Seto setelah 2006 Sumber: Marpungah, 2014.

dengan gaya yang sama berdasarkan kekhasan bentuk tari, rias dan busana tari, dan bentuk musiknya. Pengembangan tersebut terjadi di dalam komunitas yang saat itu sedang menjalankan proses pembinaan dari Dinas Pariwisata dan Kebudayaan (DISPARBUD) Kabupaten Boyolali, kemudian setelahnya hingga tahun 2006 dikembangkan lagi oleh internal komunitas yang hasilnya masih dapat diamati dan dihadirkan sampai sekarang dengan kompleksitas bentuk yang lebih variatif dan beragam unsur-unsurnya (wawancara dengan Suharmin, 22 Juni 2020). Pengembangan bentuk garap masih sering dilakukan sampai saat ini, namun dalam porsi yang tidak begitu besar atau hanya merubah atau mengembangkan sebagian unsur-unsurnya, pemadatan (peringkasan) bentuk pertunjukan, hingga perpanjangan durasi pertunjukan. Penjelasan lebih jauh mengenai praktik pengembangan pada kesenian jaranan Turonggo Seto Mardi Utomo dapat dilihat dalam tulisan Santoso (2014), Kiswanto (2018), dan Kiswanto dkk. (2019).

\section{Gebrakan Pengembangan Seni Pertunjukan Topeng Ireng Komunitas Kridho Mudo}

Seni pertunjukan (tari dan musik) Topeng Ireng pada komunitas Kridho Mudo dikembangkan pertama kali pada tahun 2005, yaitu sebagai hasil pengaruh dan persebaran pertunjukan Topeng Ireng yang awalnya tumbuh dan berkembang di Kabupaten Magelang Jawa Tengah. Pada waktu itu, bentuk seni pertunjukan Topeng Ireng masih terdiri dari dua kerangka bagian dasar, yakni laku-laku dan pakeman yang dikembangkan dan dimodikasi secara berulang, bergantian, dan berurutan hingga mencapai banyak bagian dalam setiap penyajiannya. Penyebutan lakulaku secara spesifik merujuk pada bentuk pola gerak tari berkelompok yang disajikan sambil berjalan melintas di atas lantai. Penyajian gerak tari pada setiap bagian laku-laku dibawakan beriringan dengan nyanyian sebuah lagu dari pemusiknya, yaitu lagu-lagu dalam jenis lagu rakyat Magelangan (lagu anonim), Sholawat, Campur Sari, langgam Keroncong, dan 'lagulagu Nasional'. Lagu-lagu ini dapat disajikan secara instrumental, yaitu dengan mengambil unsur melodinya melalui permainan instrumen musik yang melodis (lihat Kiswanto, 2014: 188122 \& Kiswanto, 2017: 140).

Penyebutan pakeman secara spesifik merujuk pada lagu-lagu yang dinyanyikan, antara lain adalah lagu Atur Sugeng, Atur Pambagyo, Kanca Olah Raga, Pemuda Dusun, Peringatan, Onde-onde Gandum, Rukun Islam, Kembang-kembang Mekar, dan lain-lain. Penyajian bentuk gerak tari pada setiap bagian pakeman juga dibawakan beriringan dengan nyanyian sebuah lagu dari pemusiknya, namun dengan penyajian ragam pola gerak yang lebih variatif daripada laku-laku. Penyajian ragam geraknya oleh penari berkelompok ada yang dibawakan secara serampak, perpaduan antara beberapa bentuk pola gerak berkelompok 


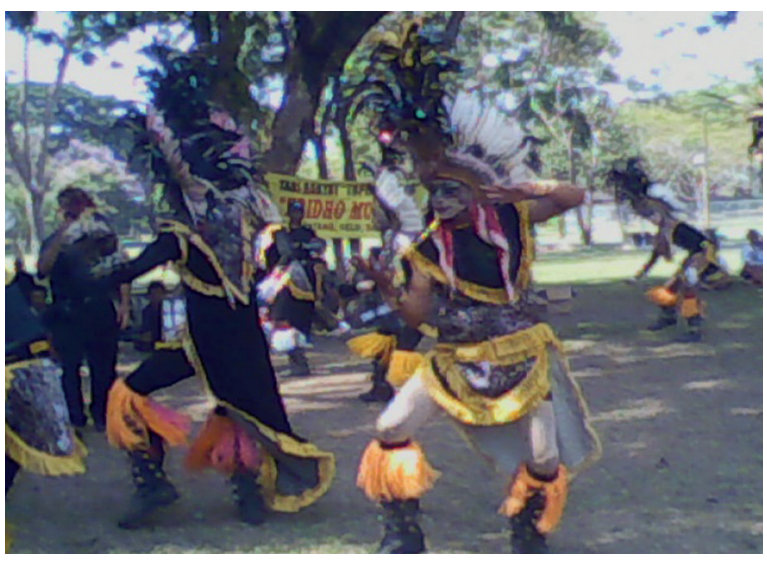

Gambar 3.

Penampilan tari Topeng Ireng Kridho Mudo versi awal

Sumber: Jefri, 2007.

yang berbeda, hingga berselang-seling yang dikombinasi dengan bentuk pola lantai yang cukup variatif (lihat Kiswanto, 2014: 138-141 \& Kiswanto, 2017: 140-141). Bentuk struktur musik yang digunakan untuk mengiringi penyajian bentuk gerak tari dan lagu pada bagian laku-laku dan pakeman adalah berbentuk pola repetitif dari permainan ritmis instrumen dog-dog (kendang satu membran, dapat juga digantikan kendang ciblon dari gamelan karawitan Jawa), bendhe (gong kecil), dan jidor (bedug berbahan kulit atau mika).

Pada tahun 2008 bentuk seni pertunjukan Topeng Ireng dalam komunitas Kridho Mudo mengalami perkembangan yang cukup signifikan, yaitu ditandai dengan adanya penambahan kerangka bagian dasar yang di dalamnya terdapat penambahan instrumen saron laras pelog (dari perangkat gamelan ageng karawitan Jawa) sebanyak dua sampai tiga buah (tentatif). Penambahan kerangka bagian dasar ini ditempatkan di antara bagian laku-laku dan pakeman, atau sebagai perantara antara bagian laku-laku dan pakeman yang secara khusus menyajikan bentuk musik bertempo cepat yang digarap dengan mengadopsi dari struktur gendhing lancaran dalam karawitan Jawa untuk dibawakan secara beriringan dengan bentuk gerakan tari yang juga bertempo cepat dengan karakter menghentak dan energik. Sejak saat itu seni pertunjukan Topeng Ireng dalam komunitas

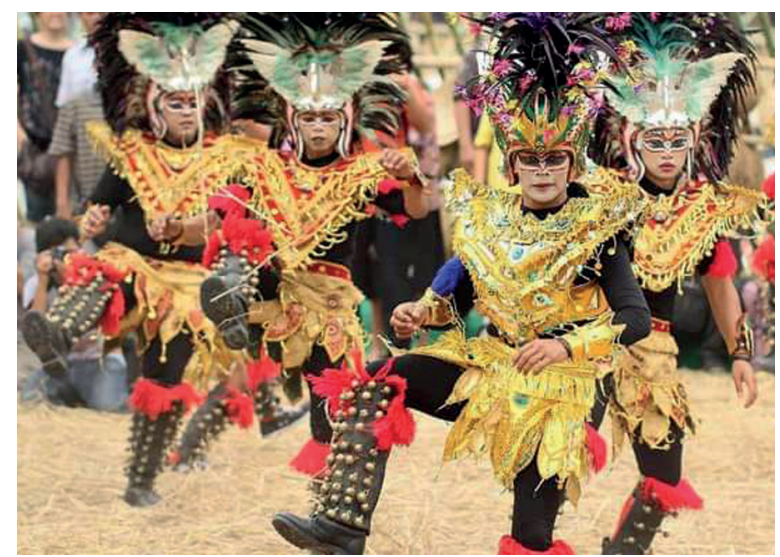

\section{Gambar 4.}

Penampilan tari Topeng Ireng Kridho Mudo setelah tahun 2009

Sumber: Theresia, 2012.

Kridho Mudo terus mengalami perkembangan secara dinamis, namun kerangka bagian-bagian dasarnya relatif tidak berubah meskipun sering dikembangkan dan dimofikasi secara fleksibel melalui penambahan dan pengurangan unsurunsur yang cenderung bersifat opsional.

Pengembangan dan modifikasi melalui penambahan dan pengurangan unsur-unsur yang bersifat opsional, misalnya dalam beberapa momen pertunjukan terdapat penambahan instrumen angklung bertangga nada diatonis untuk memberikan variasi melodis dan membawakan lagu secara instrumental, penambahan instrumen rebana yang disajikan berkelompok untuk memberikan variasi bunyi ritmis, penambahan instrumen gitar bass, drum set, dan organ, hingga penambahan aransemen dangdut dan campur sari di dalamnya (wawancara dengan Manteb Listanto, 20 Juli 2020). Pengembangan bentuk garap masih sering dilakukan sampai saat ini, namun dalam porsi yang tidak begitu besar atau hanya merubah atau mengembangkan sebagian unsur-unsurnya, pemadatan (peringkasan) bentuk pertunjukan, hingga perpanjangan durasi pertunjukan dalam rangka menyesuaikan konteks keperluan pertunjukan seperti pergelaran dalam format tradisi, karnaval, perlombaaan, acara pemerintahan, dan lain-lain. 


\section{Gebrakan Pengembangan Seni Pertunjukan Buto Gedruk Komunitas Saleho Karya Budaya}

Sejak empat tahun belakangan ini, masyarakat pelaku dan penikmat seni pertunjukan rakyat, musik dangdut, dan musik campur sari di Indonesia cukup dikejutkan dengan viralnya pertunjukan (tari dan musik) Buto Gedruk Saleho yang berkembang secara beriringan dan berdampingan dengan Orkes Dangdut MG 86, khususnya di platform Youtube hingga menembus stasiun-stasiun TV Nasional. Buto Gedruk adalah tarian bertopeng yang menggambarkan tentang sosok raksasa dalam dunia pewayangan, namun dengan ragam pola gerak yang didominasi dengan ritme gerak tubuh yang menghentak terutama pada hentakkan (gedrukan) kaki. Pada sebuah video berjudul "BUTO GEDRUK @THE SPIRIT OF REOG SALEHO” yang diunggah oleh akun @ MrDanstudio tanggal 6 Mei 2017, video tersebut pada tanggal 13 November 2020 telah ditonton oleh pemirsa sebanyak lebih dari 1,9 juta kali dan mendapatkan lebih dari 5000 like (suka). Pada unggahan video lainnya tanggal 21 September 2018 dari akun @MrDanstudio yang berjudul “BUTO GEDRUK SALEHO JOS MG 86 LIVE IN PAGUYUPAN PRABASARI KARANGSARI BARAT PULOSARI HD", video tersebut pada tanggal 13 November 2020 telah ditonton oleh pemirsa sebanyak lebih dari 5,5 Juta kali dan mendapatkan lebih dari 14.000 like (suka). Sebuah pencapaian yang cukup mengejutkan dan membanggakan mengingat sifat seni pertunjukan rakyat yang tadinya cenderung berkembang pada jangkauan lingkungan kultur yang terbatas (lihat Kayam, 1981: 60), kini dengan adanya perkembangan teknologi informasi dan komunikasi berbasis internet seperti Youtube dapat memberikan manfaat terhadap pengenalan dan penyebarluasan seni tradisonal yang berasal dari wilayah lokal untuk menjangkau wilayah nasional hingga global.

Pengaruh musik tari Buto Gedruk Saleho dan Orkes Dangdut "MG 86" cukup besar terhadap perkembangan aransemen dalam musik dangdut dan campur sari yang tumbuh dan berkembang di berbagai daerah di Jawa, yaitu aransemen dangdut dan campur sari dengan gaya musik Buto Gedruk yang karakternya dibentuk melalui permainan pola ritmis dari tiga hingga empat bendhe (memakai instrumen musik digital), drum set, dan kempul-gong (memakai instrumen musik digital). Pada mulanya, permainan pola ritmis dari ketiga buah instrumen tersebut hanya dibawakan secara khusus untuk mengiringi adegan ndadi (kesurupan) yang disertai dengan nyanyian lagi-lagu campur sari. Namun karena penonton terlihat begitu menikmati terhadap alunan musik tersebut, kemudian juga disajikan untuk mengiringi bagian kosekan dalam penyajian tari Buto Gedruk. Kosekan adalah salah satu bagian dalam sajian tari Buto Gedruk, yaitu bagian terakhir sebelum ndadi atau pertunjukan selesai. Pada bagian ini seluruh penari melepas topeng raksasa (buto) yang dikenakannya untuk saling beradu skill secara bergantian yang dibagi dalam beberapa kelompok penari dengan bentuk ragam geraknya masing-masing.

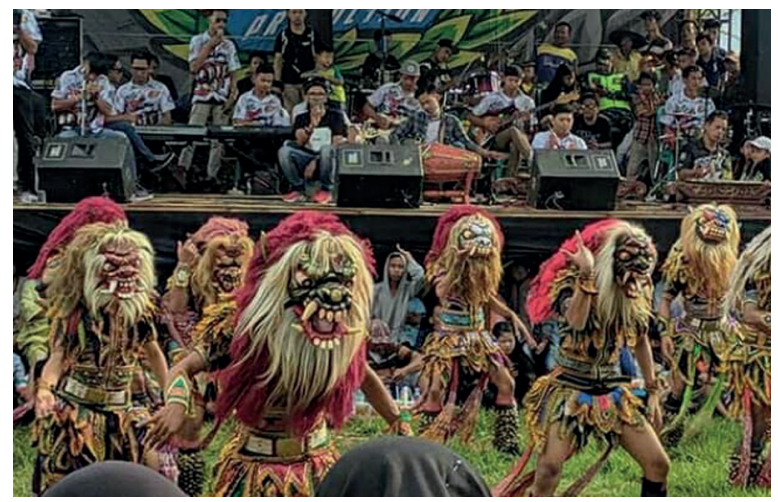

Gambar 5.

Penampilan tari dan musik Buto Gedruk Saleho yang dibawakan secara kolaboratif dengan Om MG 86

Sumber: Akbar Galang, 2019.

Seni tari dan musik Buto Gedruk dalam komunitas Saleho Karya Budaya sebenarnya merupakan hasil pengembangan pada tahun 2016 dari bentuk kesenian genre sejenis yang telah ada sebelumnya, yaitu tari dan musik Yakso Cikrak (Buto Cikrak) yang dipelajari dan dikembangkan pertama kali di dalam komunitas sejak sekitar tahun 2008-2009 melalui proses pelatihan dan penggarapan bersama beberapa pelaku kesenian serupa dari Dusun Selo Tengah, Desa Selo, Kecamatan Selo, Kabupaten Boyolali Jawa Tengah 
(wawancara dengan Agus Purwanto, 18 Juli 2020). Di dalam proses pertumbuhannya hingga berkembang bentuk pertunjukan Buto Gedruk pada tahun 2016, para penari dan pemusik yang berasal dari kecamatan Selo masih sering dilibatkan baik dalam proses kekaryaan maupun pementasan. Pertumbuhan seni pertunjukan Buto Gedruk di dalam komunitas Saleho Karya Budaya juga tidak dapat dilepaskan dari proses dialog budaya yang terjadi dengan pertumbuhan kesenian dari banyak komunitas di sekitarnya, khususnya di daerahdaerah sekitaran lereng Merapi dan Merbabu Jawa Tengah dan Yogyakarta yang secara beriringan telah banyak tumbuh kesenian dengan gaya sejenis dan saling berpengaruh secara timbal balik. Menariknya, strategi pembedaan produk komunitas Saleho Karya Budaya yang salah satunya dilakukan dengan cara menggantikan penggunaan instrumen musik bendhe dan kempul-gong ke dalam format instrumen musik digital melalui teknologi audio sampling telah menghasilkan kualitas bunyi yang mampu memberikan sentuhan karakter musikal yang kuat hingga menjadi lebih banyak diminati oleh masyarakat penikmat yang kemudian juga telah banyak diadopsi dalam musik dangdut dan campur sari.

\section{Gebrakan Melalui Penciptaan}

Gebrakan melalui penciptaan dapat diartikan sebagai suatu proses kreativitas untuk menghasilkan bentuk karya seni dengan genre atau jenis yang relatif baru, atau dalam istilah lokalnya adalah "anyar". Bentuk yang dihasilkan tampak sangat jauh berbeda dari bentuk-bentuk karya seni yang telah ada di sekitarnya, namun musik, tarian, maupun rias dan busananya masih melekatkan unsurunsur yang berciri tradisional. Gebrakan yang dilakukan melalui praktik penciptaan kemungkinan besar memiliki tingkat kesulitan dan kerumitan yang lebih tinggi daripada yang dilakukan melalui praktik pengembangan. Hanya beberapa komunitas saja yang telah melakukannya, sehingga bentuk karya seni yang lahir sebagai genre baru juga tidak sebanyak karya-karya yang dihasilkan melalui praktik pengembangan.

Karya yang lahir sebagai bentuk genre baru misalnya adalah tari Keprajuritan Nusantara dari
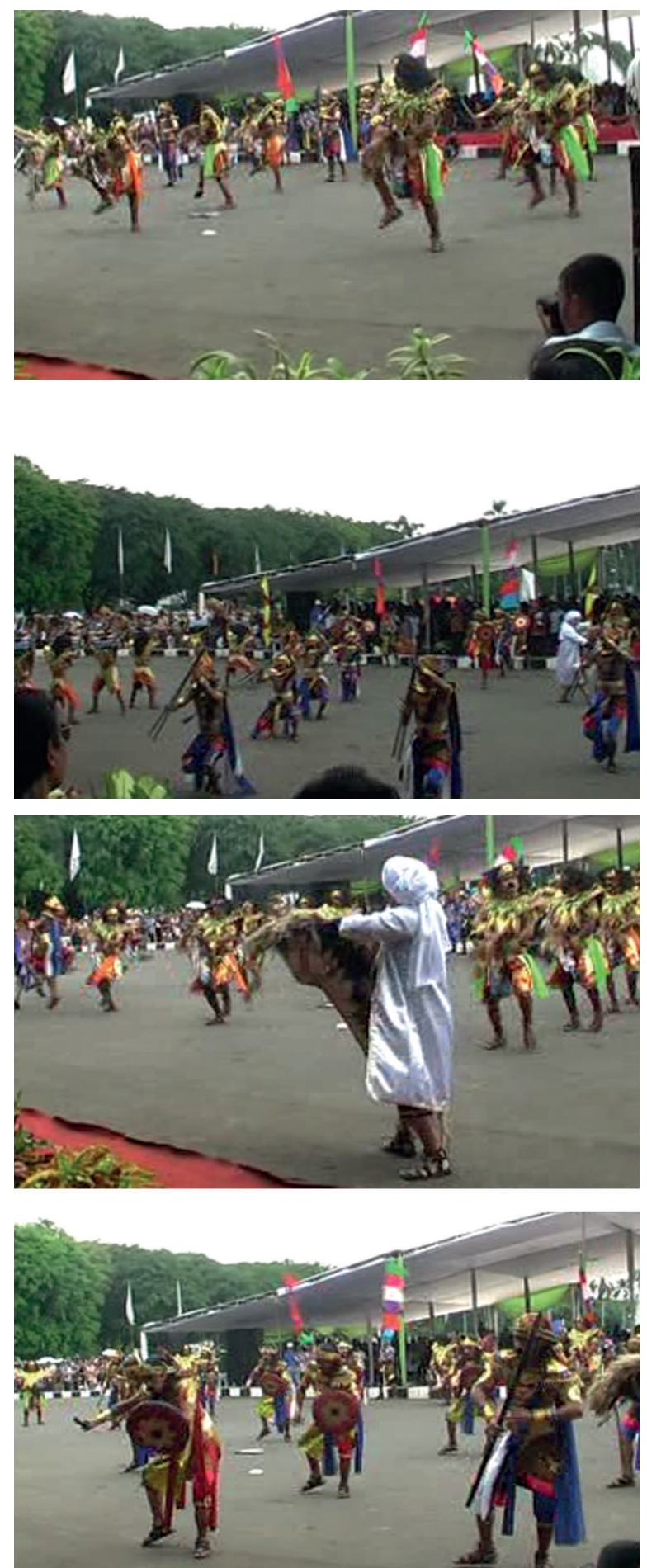

Gambar 6.

Penampilan tari Keprajuritan Nusantara pada Karnaval Keprajuritan Nusantara dalam rangka Pekan Wira Budaya di TMII

Sumber: Dinas Pariwisata dan Kebudayaan Kabupaten Boyolali, 2010. 
komunitas Turonggo Seto Mardi Utomo. Tarian ini pada mulanya tercipta pada tahun 2007 sebagai hasil modifikasi dari tari kuda kepang Turonggo Seto yang di-setting untuk pertunjukan arak-arakan, sehingga unsur-unsur di dalamnya banyak mengalami perubahan, khususnya dalam penyajian musik yang dirancang sesuai dengan penggunaan instrumen musik yang jumlahnya terbatas, bentuk gerak tarian yang dirancang untuk arak-arakan, serta terdapat penambahan peran sekelompok prajurit pembawa panji-panji (bendera). Salah satu prestasi yang membanggakan dari karya ini adalah memperoleh penghargaan sebagai Penyaji Unggulan dalam ajang Karnaval Prajurit Tradisional Nusantara di Taman Mini Indonesia Indah (TMII) Jakarta Timur pada tahun 2007.

Karya di atas kemudian dikembangkan lebih lanjut pada tahun 2010 dengan setting untuk dipertunjukan pada lokasi yang tetap maupun arak-arakan. Di dalamnya terdapat penambahan peran sekelompok prajurit bersenjata pedang dan tameng serta peran sekelompok prajurit bersenjata tombak yang diadopsi dan diadaptasikan dari bentuk seni pertunjukan tradisional yang telah berkembang sebelumnya, yaitu tari Soreng dan tari Jalantur. Salah satu prestasi yang membanggakan dari karya ini adalah memperoleh penghargaan sebagai Juara Umum, Penyaji Atraksi Terbaik, dan Penyaji Unggulan pada Karnaval Keprajuritan Nusantara dalam rangka Pekan Wira Budaya di TMII pada tahun 2010.

Di dalam komunitas Saleho Karya Budaya, karya yang lahir sebagai bentuk genre baru adalah tari Luwakan, tari Petrukan, dan tari Sakera. Luwakan diciptakan pertama kali pada tahun 2008 sebagai bentuk tarian kelompok yang menggambarkan tentang perilaku kekompakan, kegembiraan, dan permainan dari para putra rimba (anak-anak yang hidup di hutan), disertai dengan musik pengiring dari permainan instrumen saron, seruling, kendhang, jidor, tiga buah bendhe, kempul-gong, serta vokal, serta dibawakan oleh penari dan pemusik yang sebagian besar adalah anak-anak di bawah 17 tahun. Pada tahun 2011 komunitas Saleho Karya Budaya membuat karya baru dengan nama Trukecuk, atau sering juga disebut Petrukan.
Kesenian ini berbentuk tarian kelompok yang menggambarkan salah satu tokoh punakawan, yaitu Petruk dalam dunia pewayangan yang kemudian digarap dalam bentuk tarian banyolan (lucu) yang juga menyertakan unsurunsur pendidikan lewat wejangan-wejangan (pesan-pesan) yang disampaikan oleh Petruk (lewat pengisian suara dari pemusik), serta nyanyian-nyanyian tradisional Jawa. Alasan kuat yang mendorong terciptanya karya ini adalah untuk mengabadikan momen peristiwa alam gunung Merapi yang meletus pada akhir tahun 2010 silam, serta mitos tentang Kyai Petruk sebagai penunggu Gunung Merapi.

Dua tahun berselang, tepatnya pada tahun 2013, komunitas Saleho Karya Budaya membuat karya pertunjukan tari dan musik yang baru dengan nama Sakera. Kesenian ini merupakan bentuk tarian kelompok yang menggambarkan tentang keliaran binatang kera yang berada di sekitar Gunung Merapi. Tarian ini terinspirasi dari sekawanan kera yang sering mendadak turun dari habitatnya di Gunung Merapi, memakan dan merusak tanaman para petani yang mengakibatkan petani gagal panen. Kondisi yang hampir serupa juga terjadi sebelum dan saat Gunung Merapi mengalami erupsi pada tahun 2010, hal ini juga turut memberikan inspirasi dalam menciptakan tari Sakera.

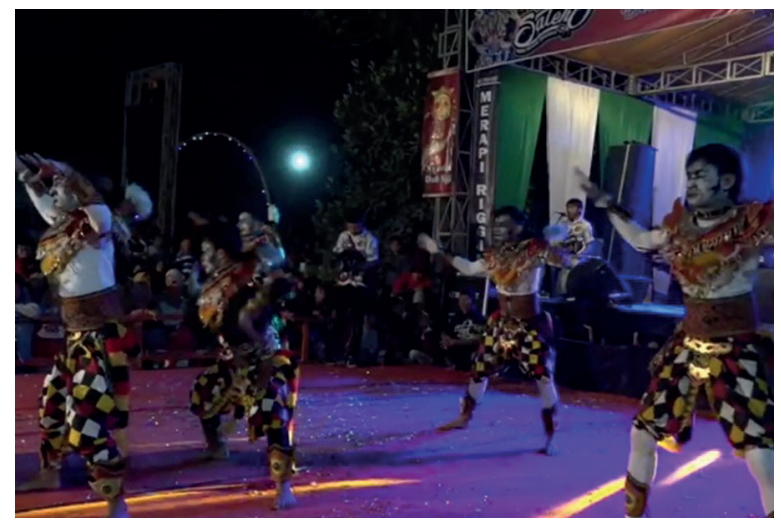

Gambar 7.

Penampilan tari Sakera

Sumber: CXHD Video Shooting, 2019.

\section{Gebrakan Melalui Adopsi}

Praktik adopsi suatu bentuk seni pertunjukan yang berasal dari komunitas lain dari dalam maupun luar daerah sebenarnya 
merupakanfemonena umum yang sering terjadi di antara komunitas seni pertunjukan rakyat di Boyolali, namun tidak semuanya dapat dikatakan sebagai gebrakan karena di antaranya masih banyak yang hasilnya memiliki banyak unsur kesamaan dengan bentuk-bentuk seni pertunjukan lain di sekitarnya. Praktik adopsi ini dalam tahap yang lebih lanjut juga dapat menjadi gebrakan apabila telah melalui proses pengembangan seperti yang telah diuraikan sebelumnya, yaitu pada pengembangan seni pertunjukan tari kuda kepang Turonggo Seto Mardi Utomo yang kemudian juga menjadi bekal dasar dalam penciptaan seni pertunjukan tari Keprajuritan Nusantara.

Gebrakan melalui praktik adopsi biasanya terjadi ketika karya yang dihadirkan benarbenar memiliki daya tarik dan keunikan tersendiri yang berbeda dengan berbagai macam bentuk seni pertunjukan yang tumbuh di lingkungan sekitar, yaitu menghadirkan karya baru melalui praktik adopsi dan adaptasi dari suatu jenis seni pertunjukan yang berasal dari daerah lain. Hal ini menjadi bagian dari strategi beberapa komunitas dalam upayanya untuk meningkatkan peluang penawaran, khususnya di tingkat lokal, dengan pertimbangan bahwa karya yang dihadirkan tampak jauh berbeda dengan karya-karya lain yang ada di sekitarnya. Hal itu dapat dijumpai dalam beberapa contoh, misalnya adalah gebrakan menghadirkan seni pertunjukan Reog Ponorogo di Boyolali yang dilakukan

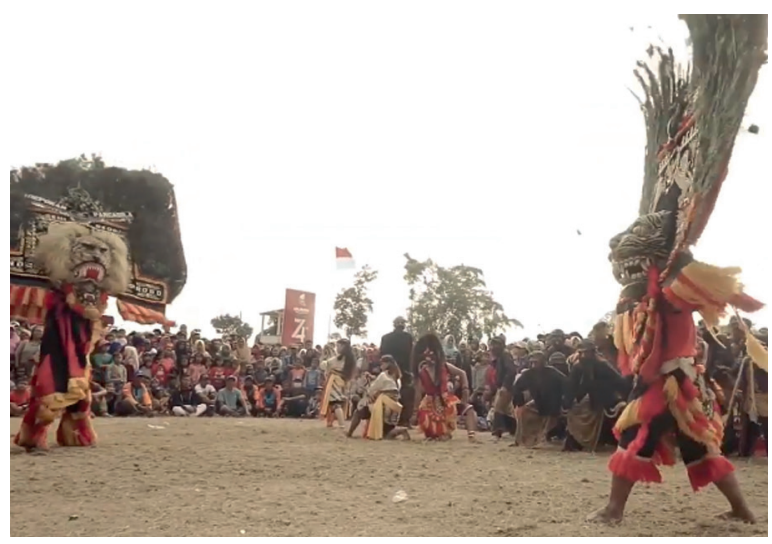

Gambar 8.

Penampilan tari Reog dari komunitas Turonggo Seto Mardi Utomo Sumber: Doni Risma, 2019.

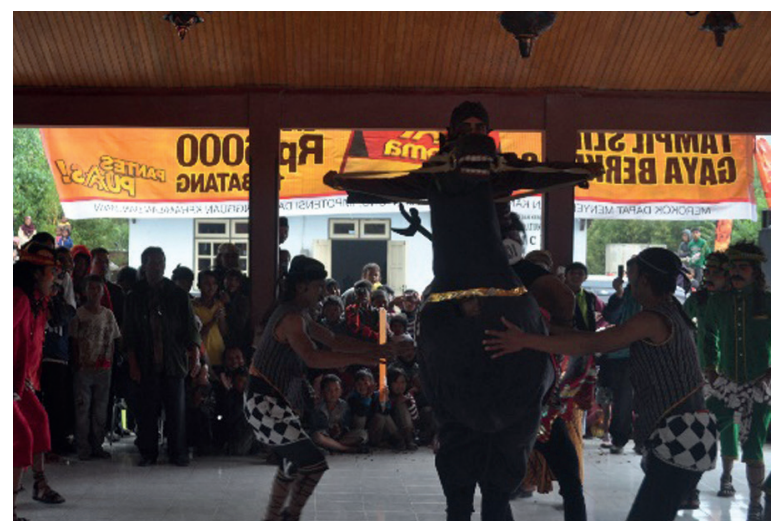

Gambar 9.

Penampilan tari Soreng Sri Rahayu dari Dusun Cangkol Ngisor, Lencoh, Selo, Boyolali. Sumber: Dokumentasi Dinas Pariwisata dan

Kebudayaan Kabupaten Boyolali, 2012.

oleh Komunitas Turonggo Seto Mardi Utomo, serta gebrakan menghadirkan seni pertunjukan Soreng (sebaran dari Magelang) di Boyolali yang dilakukan oleh sejumlah komunitas.

\section{Strategi dan Pola Penganekaragaman}

Praktik pengembangan, penciptaan, ataupun praktik adopsi bentuk karya seni yang terjadi antar komunitas seni pertunjukan rakyat di Boyolali tidak dapat dilepaskan dari upaya penganekaragaman yang diorientasikan sebagai strategi untuk memperkuat positioning komunitas dalam menghadapi persaingan pasar. Positioning dalam hal ini dapat diartikan seperti penjelasan Kotler dan Keller (2009: 292; lihat juga Dwihapsari \& Murni, 2017: 105) yang berasal dari disiplin ekonomi, yaitu sebagai tindakan merancang untuk menghasilkan penawaran dan membentuk citra perusahaan (atau komunitas) agar mendapatkan tempat khusus dalam pikiran pasar sasaran, sehingga membuat produk melesat dan tampak jauh berbeda dari produk-produk lainnya.

Menurut Agus Purwanto (wawancara 18 Juli 2020), strategi yang dilakukan oleh Komunitas Saleho Karya Budaya dalam memperjuangkan eksistensi adalah selalu berupaya menambahkan dan menghasilkan karya baru yang unik dan berbeda dari komunitas lain. Baik dari segi garap tarian, maupun dari segi garap musiknya agar dapat menyediakan berbagai macam pilihan bentuk 
karya seni yang menarik dan sesuai dengan kebutuhan dan selera masyarakat yang terus mengalami perubahan secara dinamis. Strategi yang lainnya adalah berkarya dengan mengikuti perkembangan trend yang ada agar karya yang dihasilkan dapat dengan mudah diterima oleh masyarakat, namun juga harus diikuti dengan pembedaan dari komunitas lain untuk membentuk karakter dan ciri khas yang mampu memberikan daya tarik untuk selalu ditunggu dan dinanti oleh penontonnya.

Penjelasan mengenai strategi pemberagaman yang dilakukan oleh komunitas Saleho Karya Budaya di atas dapat dijadikan sebagai cerminan mengenai proses penganekaragaman bentuk karya seni yang terjadi dan terjalin di antara komunitas seni pertunjukan rakyat di Boyolali. Proses dan hasil dari penganekaragaman dapat diperoleh melalui praktik pengembangan, praktik penciptaan, ataupun melalui praktik adopsi, namun dengan syarat bahwa bentuk-bentuk seni pertunjukan yang lama masih tetap disediakan dan dipertahankan sebagai suatu entitas dengan genre, gaya, ataupun versi yang berbeda. Penganekaragaman dalam hal ini juga dapat diartikan sebagai suatu kegiatan pengembangan, namun dengan orientasi pada pemambahan (memperkaya) jumlah karya seni dengan jenis, gaya, ataupun versi yang beranekaragam. Ciri-cirinya dapat dikenali dengan adanya pola pengembangan jumlah karya seni yang berbeda satu lain pada hampir setiap komunitas, sedangkan berbagai macam bentuk karya seni yang dimiliki pada hampir setiap komunitas juga saling dibedakan satu sama lain dengan bentuk-bentuk kaya seni dari komunitas-komunitas lain di sekitarnya.

Proses dan hasil dari penganekaragaman bentuk karya seni pertunjukan yang terjadi di antara komunitas Turonggo Seto Mardi Utomo, komunitas Saleho Karya Budaya, dan komunitas Kridho Mudo dapat digambarkan secara lebih ringkas, padat, dan jelas pada tabel berikut ini.

Tabel 1.

Penganekaragaman Bentuk Karya Seni Pada Antar Komunitas Tahun 1992 - 2020

\begin{tabular}{|c|c|c|c|c|}
\hline & $\begin{array}{c}\text { Komunitas Turonggo Seto Mardi } \\
\text { Utomo }\end{array}$ & $\begin{array}{l}\text { Komunitas } \\
\text { Kridho Mudo }\end{array}$ & $\begin{array}{c}\text { Komunitas } \\
\text { Saleho Karya Budaya }\end{array}$ & $\begin{array}{l}\text { Tahun Awal } \\
\text { Pengembangan }\end{array}$ \\
\hline \multirow{12}{*}{ 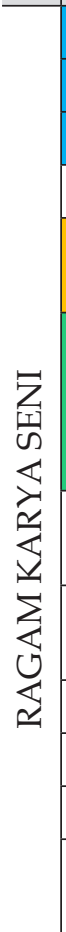 } & Reog Jaranan & & & 1992 \\
\hline & Jaranan Turonggo Kencono & & & 1998 \\
\hline & Jaranan Turonggo Seto & & & 1999 \\
\hline & & Topeng Ireng & & 2005 \\
\hline & Prajuritan & $\begin{array}{l}\text { Warokan } \\
(2007-2009) \\
\end{array}$ & & 2007 \\
\hline & $\begin{array}{l}\text { Pertunjukan Kolosal Reog } \\
\text { Ponorogo: Warokan, Jathilan, } \\
\text { Pujangga Anom, Dadak Merak, } \\
\text { Klono Sewandono }\end{array}$ & & $\begin{array}{l}\text { Buto Cikrak } \\
(2008-2016)\end{array}$ & 2008 \\
\hline & & & $\begin{array}{l}\text { Luwakan } \\
(2008-2009)\end{array}$ & 2008 \\
\hline & & & $\begin{array}{l}\text { Jaranan Campur Sari } \\
(2008-2009)\end{array}$ & 2008 \\
\hline & & & Jaranan Garap Baru & 2009 \\
\hline & & & Topeng Ireng & 2009 \\
\hline & & Jaranan & Prajuritan & 2011 \\
\hline & & $\begin{array}{l}\text { Buto Cikrak } \\
(2011-2014)\end{array}$ & & 2011 \\
\hline
\end{tabular}




\begin{tabular}{l|l|l|l|l}
\hline \multicolumn{1}{|c|}{$\begin{array}{c}\text { Komunitas Turonggo Seto Mardi } \\
\text { Utomo }\end{array}$} & $\begin{array}{c}\text { Komunitas } \\
\text { Kridho Mudo }\end{array}$ & $\begin{array}{c}\text { Komunitas } \\
\text { Saleho Karya Budaya }\end{array}$ & $\begin{array}{c}\text { Tahun Awal } \\
\text { Pengembangan }\end{array}$ \\
\hline Topeng Ireng & $\begin{array}{l}\text { Grasak } \\
(2012-2014)\end{array}$ & Petrukan / Trokecuk & 2012 \\
\hline Jaranan Prajurit Tamtama & & Sakera & 2014 \\
\hline $\begin{array}{l}\text { Lembu Kanaka } \\
(2015-2016)\end{array}$ & & & 2015 \\
$\begin{array}{l}\text { Tanen } \\
(2015-2016)\end{array}$ & & & 2015 \\
\hline & & & 2016 \\
\hline Buto Gedruk & Buto Gedruk & Buto Gedruk & 2018 \\
\hline & & & 2019 \\
\hline
\end{tabular}

Sumber: Dihimpun dari komunitas Turonggo Seto Mardi Utomo, komunitas Kridho Mudo, dan komunitas Saleho Karya Budaya, 2020.

Pemberian warna di dalam kolomkolom tabel di atas adalah bertujuan untuk menunjukkan persamaan dan perbedaan antara bentuk kesenian yang satu dengan yang lainnya. Pemberian warna yang sama pada beberapa kolom yang berbeda adalah untuk menunjukkan bahwa kesenian yang disebutkan di dalamnya termasuk dalam kategori genre seni pertunjukan yang sama, namun dengan pengembangan bentuk garap dan gaya yang dapat berbeda satu sama lain. Sementara itu pemberian warna yang berbeda antar beberapa kolom adalah untuk menunjukkan perbedaan genre antara kesenian-kesenian yang disebutkan di dalamnya.

Berbagai ragam jenis karya seni yang disebutkan pada daftar di atas masih terus dilestarikan dan dikembangkan secara dinamis hingga saat ini, kecuali yang diberikan keterangan tahun dalam tanda kurung di bawah nama yang hanya tumbuh dalam kurun waktu yang terbatas, di antaranya karena sudah bertransformasi menjadi jenis dan bentuk seni pertunjukan yang lain, ataupun karena memang sudah tidak dibutuhkan lagi oleh para pelaku dan masyarakat penikmatnya. Pengembangan yang dilakukan melalui upaya kreativitas untuk menambah dan menghasilkan bentuk karya seni yang dibedakan satu sama lain semacam itu, apabila dikaitkan dengan penjelasan Chamberlin (1969: 56 \& 65) dapat dikategorikan sebagai bentuk strategi pembedaan produk (differentitation of product) yang bertujuan untuk memegang kendali atas persaingan pasar melalui preferensi yang ditawarkan. Chamberlin (1969: 65-67) menyebutnya sebagai bentuk persaingan monopolistik (monopolistic competition), sebab persaingannya berlangsung dengan cara pembedaan-pembedaan dari kategori umum (tari rakyat) produk-produk kompetitor yang heterogen. Pembedaan (diferensiasi) produk dari kategori umumnya berpotensi menciptakan pasar sendiri bersama konsumennya, karena tidak ada ketersediaan (supply) produk yang sama untuk melayani permintaan (demand) pasar.

Di sisi lain, proses penganekaragaman yang menjadi strategi komunitas untuk memperkuat positioning-nya dalam menghadapi situasi dan kondisi pasar memiliki kemiripan dengan konsep diversifikasi produk yang dijelaskan oleh Effendi (1996: 109), yaitu sebagai suatu perluasan pemilihan barang dan jasa yang dijual oleh perusahaan dengan jalan menambah produk baru atau jasa ataupun memperbaiki tipe, warna, mode, ukuran, jenis dari produk yang sudah ada dalam rangka memperoleh laba maksimal. Selain itu, Kotler (2001:69) juga menjelaskan bahwa diversifikasi produk merupakan salah satu cara yang dapat dilakukan oleh perusahaan untuk meningkatkan kinerja bisnis dengan jalan mengidentifikasi peluang untuk menambah bisnis yang tidak berkaitan dengan bisnis perusahaan yang ada sebelumnya. 


\section{SIMPULAN}

Penelitian ini menunjukkan bahwa teori monopolistic competition yang diadopsi dan diadaptasi dari disiplin ilmu ekonomi memiliki relevansi untuk menjelaskan fakta-fakta pertumbuhan seni pertunjukan yang terkait erat dengan persaingan yang terjadi dan terjalin di antara komunitas seni pertunjukan rakyat di Boyolali. Meskipun demikian, pemakaian istilah kompetisi atau persaingan ternyata memiliki citra yang cenderung 'kurang pantas' apabila dinyatakan secara eksplisit di kalangan komunitas pelaku seni pertunjukan rakyat. Para pelaku lebih lazim menggunakan istilah gebrakan untuk mengartikan orientasi kegiatannya dalam kekaryaan dan pementasan karya seni yang tidak hanya sekedar menghasilkan kebaruan, melainkan juga menghasilkan daya tarik yang mampu mengejutkan, menghebohkan, dan memikat perhatian banyak orang untuk mengapresiasi serta mengagumi.

Budaya monopolistic competition dalam penelitian ini dapat dimaknai secara khusus sebagai bentuk pola persaingan tidak langsung antar komunitas seni pertunjukan rakyat dalam rangka memenuhi perkembangan kebutuhan estetis, serta sebagai upaya untuk meningkatkan kebutuhan tanggapan. Ciri-cirinya dapat dikenali dengan adanya pola pengembangan dan penganekaragaman bentuk karya seni pada antar komunitas yang dilakukan dengan cara menambahkan dan menghasilkan bentukbentuk karya seni yang saling dibedakan satu sama lain, baik dari karya-karya sendiri di dalam internal komunitas, maupun dari karyakarya komunitas-komunitas lain di sekitarnya. Pola tersebut terbangun melalui proses dan hasil kreativitas dari praktik pengembangan, penciptaan, dan/atau adopsi bentuk karya seni pada antar komunitas yang didasari atas maksud untuk membuat dan menghadirkan suatu gebrakan. Di sisi lain, proses tersebut juga menjadi bagian dari strategi dan pola penganekaragaman bentuk karya seni yang dilakukan untuk memperkuat positioning komunitas dalam menghadapi persaingan pasar. Pola dan strategi yang terbangun di dalamnya telah memberikan dampak positif terhadap pertumbuhan seni pertunjukan rakyat yang semakin bertambah banyak ragamnya, sehingga tersedia banyak pilihan bentuk karya seni yang saling bersaing agar dapat dipilih untuk disaksikan ataupun dipesan untuk dipergelarkan.

\section{DAFTAR PUSTAKA}

Anoegrajekti, N. (2011). Gandrung Banyuwangi: Kontestasi dan Representasi Identitas Using. Humaniora, 23(1), 1-15. Retrieved from https://jurnal.ugm.ac.id/jurnalhumaniora/article/view/1007/836

Bennett, T. (2015). Cultural Studies and the Culture Concept. Cultural Studies, 29(4), 546-568. doi: 10.1080/09502386.2014.1000605

Chamberlin, E. H. (1969). The Theory of Monopolistic Competition. A Re-orientation of the Theory of Value. (8th Edition, 3rd Printing). Cambridge, Mass.: Harvard University Press.

Dinas Pendidikan dan Kebudayaan Kabupaten Boyolali. (2017). Data Kelompok Kesenian Kabupaten Boyolali Tahun 2017. (Unpublished). Boyolali.

Dwihapsari, E. R., \& Murni, Y. (2017). Pengaruh Positioning, Diferensiasi dan Citra Merek terhadap Keputusan Pembelian Buku Mimpi Sejuta Dolar dengan Promosi sebagai Variabel Intervening. E-Journal Widya Ekonomika, 1(2), 112-119. Retrieved from https://e-journal. jurwidyakop3.com/index.php/ ekonomika/article/view/269

Effendi, R. (1996). Marketing Management. Malang: Penerbit IKIP Malang.

Fitriasari, R. P. D., Haryono, T., Simatupang, G. R. L. L., \& Abdullah, I. (2012). Ritual Sebagai Media Transmisi Kreativitas Seni di Lereng Gunung Merbabu. Jurnal Kawistara, 2(1), 25-35. Retrieved from https:// jurnal.ugm.ac.id/kawistara/article/ view/3933/3214 
Hunt, S. D. (2011). The Theory of Monopolistic Competition, Marketing's Intellectual History, and the Product Differentiation Versus Market Segmentation Controversy. Journal of Macromarketing, 31(1), 73-84. doi: $10.1177 / 0276146710382119$

Kayam, U. (1981). Seni, Tradisi, Masyarakat. Jakarta: Penerbit Sinar Harapan.

Kiswanto. (2014). Konsepsi Pemaknaan Kelinthing dalam Pertunjukan Topeng Ireng. (Unpublished Thesis). Institut Seni Indonesia Surakarta.

Kiswanto. (2018). Transformasi Multipel Seni Kuda Kepang Kelompok Turonggo Seto Mardi Utomo Boyolali Jawa Tengah. (Unpublished Thesis). Universitas Gadjah Mada.

Kiswanto, K. (2017). Transformasi BentukRepresentasi dan Performativitas Gender dalam Seni Tradisi Topeng Ireng. Jurnal Kajian Seni, 3(2), 136-149. Retrieved from https://jurnal.ugm. ac.id/jks/article/view/22706/18103

Kiswanto, K. (2019). Transformasi Multipel dalam Pengembangan Seni Kuda Kepang. Dance and Theatre Review, 2(1), 1-16. doi: 10.24821/dtr. v2i1.3295

Kotler, P. (2001). Manajemen Pemasaran: Analisis, Perencanaan, Implementasi, dan Kontrol. Jakarta: PT. Prehallindo..

Kotler, P., \& Keller, K. L. (2009). Manajemen Pemasaran Jilid 1 (13th ed.). Jakarta: Erlangga.

Marcuello, C., \& Salas, V. (2001). Nonprofit Organizations, Monopolistic Competition, and Private Donations: Evidence from Spain. Public Finance Review, 29(3), 183-207. doi: $10.1177 / 109114210102900301$

Mesoudi, A. (2011). Cultural Evolution: How Darwinian Theory Can Explain Human Culture and Synthesize the Social Sciences. Chicago and London: University of Chicago Press.
Murgiyanto, S. (2017). Kritik Pertunjukan dan Pengalaman Keindahan (D. Pramayoza, Ed.). Yogyakarta: Prodi Pengkajian Seni Pertunjukan dan Seni Rupa Sekolah Pascasarjana Universitas Gadjah Mada dan Komunitas SENREPITA.

Nurngaeni, E., Karkono, D. T., \& Supriadi. (2019). Reproduksi Seni Pertunjukan Lengger Banyumas pada Kelompok Seni Kencana Laras dalam Perspektif Bourdieus. Peran Akademisi Di Era Revolusi Industri 4.0 Dan Society 5.0 Dalam Mengembangkan IPTEKS. Temanggung: Lembaga Bahasa Sekolah Tinggi Agama Islam Nahdlatul Ulama Temanggung. Retrieved from https:/ / inisnu.ac.id/ prosiding-evi-nurngaeni-drajattri-karkono-supriadi-universitassebelas-maret-surakarta/

Pigeaud, T. (1991). Pertunjukan Rakyat Jawa: Sumbangan bagi Ilmu Antropologi (Terjemahan; M. H. Pringgokusumo, Ed.). Surakarta: Dinas Urusan Istana Mangkunegaran Rekso Pustoko.

Poerwadarminta, W. J. S. (1939). Bausastra Jawa. Groningen: JB Wolters' Uitgevers Maatschappij.

Radhia, H. A. (2016). Dinamika Seni Pertunjukan Jaran Kepang di Kota Malang. Jurnal Kajian Seni, 2(2). Retrieved from https://jurnal.ugm. ac.id/jks/article/view/12140/15099

Rice, T. (2014). Ethnomusicology: a very short introduction. New York: Oxford University Press.

Santoso. (2014). Tari Turonggo Seto; Sebuah Kreasi Baru Berbasis Rakyat. (Unpublished Thesis). Institut Seni Indonesia Surakarta.

Simatupang, L. (2013). Pagelaran: Sebuah Mozaik Penelitian Seni-Budaya (D. Pramayoza, Ed.). Yogyakarta: Jalasutra.

Soedarsono, R. M. (2010). Seni Pertunjukan Indonesia di Era Globalisasi. 
Yogyakarta: Gadjah Mada University Press.

Soemaryatmi, \& Suharji. (2015). Sosiologi Seni Pertunjukan Pedesaan (A. Rosmiati, Ed.). Surakarta: ISI Press.

Tylor, E. B. (1871). Primitive culture: Researches into the development of mythology, philosophy, religion, art and custom. London: J. Murray.

Williams, R. (1965). The Long Revolution (Pelican Books) (Revised). Ringwood: Penguin Books Ltd.

\section{DAFTAR NARASUMBER}

1. Suharmin (52 Tahun), Ketua Komunitas Turonggo Seto Mardi Utomo Dusun Salam, Desa Samiran, Kecamatan Selo Kabupaten Boyolali.

2. Manteb Listanto (28 Tahun), Kreator dan Pelaku Seni Komunitas Kridho Mudo Dusun Tarusari, Kelurahan Tarubatang, Kecamatan Selo, Kabupaten Boyolali

3. Agus Purwanto (35 Tahun), Kreator dan Pelaku Seni Komunitas Saleho Karya Budaya Dusun Bendolegi, Kelurahan Cluntang, Kecamatan Musuk, Kabupaten Boyolali. 